Open Access

\title{
The striking and unexpected cytogenetic diversity of genus Tanacetum L. (Asteraceae): a cytometric and fluorescent in situ hybridisation study of Iranian taxa
}

\author{
Nayyereh Olanj ${ }^{1,2}$, Teresa Garnatje ${ }^{3}$, Ali Sonboli ${ }^{4}$, Joan Vallès ${ }^{2}$ and Sònia Garcia ${ }^{2 *}$ (i)
}

\begin{abstract}
Background: Although karyologically well studied, the genus Tanacetum (Asteraceae) is poorly known from the perspective of molecular cytogenetics. The prevalence of polyploidy, including odd ploidy warranted an extensive cytogenetic study. We studied several species native to Iran, one of the most important centres of diversity of the genus. We aimed to characterise Tanacetum genomes through fluorochrome banding, fluorescent in situ hybridisation (FISH) of rRNA genes and the assessment of genome size by flow cytometry. We appraise the effect of polyploidy and evaluate the existence of intraspecific variation based on the number and distribution of GC-rich bands and rDNA loci. Finally, we infer ancestral genome size and other cytogenetic traits considering phylogenetic relationships within the genus.
\end{abstract}

Results: We report first genome size (2C) estimates ranging from 3.84 to $24.87 \mathrm{pg}$ representing about $11 \%$ of those recognised for the genus. We found striking cytogenetic diversity both in the number of GC-rich bands and rDNA loci. There is variation even at the population level and some species have undergone massive heterochromatic or rDNA amplification. Certain morphometric data, such as pollen size or inflorescence architecture, bear some relationship with genome size. Reconstruction of ancestral genome size, number of CMA+ bands and number of rDNA loci show that ups and downs have occurred during the evolution of these traits, although genome size has mostly increased and the number of CMA+ bands and rDNA loci have decreased in present-day taxa compared with ancestral values.

Conclusions: Tanacetum genomes are highly unstable in the number of GC-rich bands and rDNA loci, although some patterns can be established at the diploid and tetraploid levels. In particular, aneuploid taxa and some odd ploidy species show greater cytogenetic instability than the rest of the genus. We have also confirmed a linked rDNA arrangement for all the studied Tanacetum species. The labile scenario found in Tanacetum proves that some cytogenetic features previously regarded as relatively constant, or even diagnostic, can display high variability, which is better interpreted within a phylogenetic context.

Keywords: 5S, 35S, Aneuploidy, Evolutionary cytogenetics, Genomic instability, L-type arrangement, Polyploidy, Odd ploidy, Ribosomal DNA

\footnotetext{
* Correspondence: soniagarcia@ibb.csic.es

${ }^{2}$ Laboratori de Botànica - Unitat associada CSIC, Facultat de Farmàcia,

Universitat de Barcelona, Avinguda Joan XXIII s/n, 08028 Barcelona, Catalonia,

Spain

Full list of author information is available at the end of the article
} 


\section{Background}

Tanacetum L. is a genus of the family Asteraceae Bercht. \& J. Presl and includes approximately 160 species [1]. It is one of the largest genera within the tribe Anthemideae Cass., together with genera such as Artemisia L., Achillea L. and Anthemis L. Commonly known as tansies, Tanacetum species are native to many areas of the Northern Hemisphere, occupying the temperate zones of Europe, Asia, North Africa and North America, but particularly abundant in the Mediterranean and Irano-Turanian regions. Although the presence of Tanacetum in the Southern Hemisphere is much less common [1, 2], some species are grown worldwide such as T. parthenium (L.) Sch. Bip., which can behave as a weed outside its native range.

Tanacetum species are mostly perennial herbs, although the genus has some annuals and some subshrubs. They usually form rhizomes and are aromatic plants. Their capitula, solitary or arranged in more or less dense or loose compound inflorescences, always contain disc flowers (flosculous, yellow, numerous - up to 300), sometimes with ray flowers (ligulate, white, yellow or pale pink). Tanacetum is considered to hold a crucial position for understanding the phylogenetic relationships within its tribe, but available phylogenetic reconstructions show that these species form an imbroglio whose generic relationships and infrageneric arrangement are still unsettled [3]. Many species of Tanacetum are widely distributed and are used as sources of medicines, food or forage. In particular, several studies have shown that essential oils from $T$. parthenium [4-6] and T. balsamita L. [7-9] have strong antibacterial, cytotoxic, neuroprotective and antioxidant activity. T. balsamita has also shown anti-inflammatory properties [10]. West and central Asia are two important speciation centres of the genus [11], and Iran is one of the main areas of speciation and diversification, promoted by a unique combination of ecosystems. In Iran the genus is represented by 36 species according to the most recent revisions, including 16 endemic taxa [3, 12-17].

The karyology of Tanacetum has been extensively studied, with chromosome counts known for a considerable number of its species [18-21]. Its basic chromosome number is $x=9$, as in most Anthemideae and Asteraceae; indeed $x=9$ is likely the ancestral basic number for the family as a whole [22]. Ploidy levels are found up to $10 \times$ [23]. Recent work has added more karyological information for this genus; it seems that polyploidy is an important evolutionary force and the existence of odd ploidy, aneuploidy and presence of B-chromosomes is not uncommon $[18,20]$.

Methods such as fluorochrome banding and fluorescent in situ hybridisation (FISH) of $5 \mathrm{~S}$ and $18 \mathrm{~S}-5.8 \mathrm{~S}-26 \mathrm{~S}$ (35S) ribosomal RNA genes (rDNA) provide chromosome markers, excellent tools to improve karyotype description [24]. These methods have proven useful for comparing taxa at different levels, particularly in plants (see, for example, [25] on several Asteraceae genera; [26], on Fragaria L.; [27] on Thinopyrum Á. Löve). However broader cytogenetic information is largely missing for Tanacetum, as happens for many wild species, unlike crops or other economically interesting plants whose chromosomes have been more deeply investigated. Genome size estimation, easily obtained by flow cytometry, has been used in a similar way (see, for example, [28] on Tripleurospermum Sch. Bip.; [29] on Carthamus L.; [30] on Artemisia L.). The combination of these methods can improve our understanding of chromosome evolution and genome organisation processes in plants [31]. Moreover, molecular cytogenetic studies, together with genome size evaluation, are also useful in a wide range of biological fields, from taxonomy, evaluation and conservation of genetic resources, to plant breading [24, 32-34].

Despite being a large and well-known genus, molecular cytogenetic studies of Tanacetum are limited to a single work reporting data on two species: $T$. achilleifolium (M. Bieb.) Sch. Bip. and T. parthenium [35]. That study described co-localisation of both $5 \mathrm{~S}$ and $35 \mathrm{~S}$ ribosomal RNA genes in Tanacetum, the so-called linked type (L-type) arrangement of rDNA, confirming preliminary findings for this genus [25]. This rDNA organisation is typical of several Asteraceae members, particularly those belonging to tribes Anthemideae and the Heliantheae Cass. alliance (see $[25,36]$ for details). However, the most common rDNA organisation in plants, and also in family Asteraceae, is that in which both rRNA genes are separated (S-type arrangement). Remarkably, [35] found that one 35S rDNA locus was separated in T. achilleifolium, while the other one remained co-localised with the $5 \mathrm{~S}$. This dual organisation of rDNA in the same species (i.e. both L-type and S-type coexisting) is exceptional.

Likewise, genome sizes for Tanacetum are only known for few species, reduced to three research works to our knowledge [37-39]. In this study, we establish a deeper knowledge of Tanacetum genomes through molecular cytogenetic and genome size analysis. We focus on several species native to Iran, since this area constitutes a centre of speciation and diversification of the genus. All ploidy levels previously reported for the genus (from $2 \mathrm{x}$ to $10 \mathrm{x}$ ) exist in Iran [20], many of the studied tansies grow there in polyploid series, and odd stable ploidy, aneuploidy and presence of B-chromosomes have been found $[3,20]$. Our specific goals were (1) to characterise the genomes of Tanacetum species by flow cytometry, fluorochrome banding and FISH of rRNA genes, and particularly, to observe the rDNA organisation in these species, (2) to detect the karyotype and genome size patterns of the genus and describe their typical models, if any, (3) to address the presence of polymorphisms at 
the cytogenetic level, (4) to assess the impact of polyploidy in Tanacetum genomes, and (5) to reconstruct ancestral character states of genome size and karyotype features such as number of rDNA loci and CMA+ bands to infer genome evolution in the context of a phylogenetic framework of the genus.

\section{Results}

The chromosome counts here represent most ploidy levels found in Tanacetum to present, all $\mathrm{x}=9$-based. We found B-chromosomes in one of the populations of $T$. pinnatum and in T. fisherae, and some of the populations investigated, such as those of $T$. archibaldii and $T$. aureum (Lam.) Greuter, M.V.Agab. \& Wagenitz, presented mixed ploidy. In addition, several of the studied taxa are odd polyploids, such as the case of triploid $T$. joharchii Sonboli \& Kaz. Osaloo and T. kotschyi (Boiss.) Grierson, and the pentaploid T. fisherae Aitch. \& Hemsl. which is also a hypoaneuploid since it has lost one chromosome out of the 45 expected. More detailed karyological information is in Table 1.

\section{Genome size}

Table 1 presents holoploid genome size data (2C), together with other karyological features of the studied species, as well as information on some closely related taxa for comparison. We analysed 38 populations of 20 species and five subspecies of Tanacetum, including ploidy from $2 \mathrm{x}$ to $6 \mathrm{x}$. Genome sizes $(2 \mathrm{C})$ ranged from $3.84 \mathrm{pg}$ (belonging to one of the diploid populations of T. parthenium) to $24.87 \mathrm{pg}$ (from a tetraploid population of T. pinnatum Boiss.), an overall 6.47-fold range, and a 3.29-fold range at the diploid level. Mean 2C at diploid level is $8.05 \mathrm{pg}$. The low Half Peak Coefficient of Variation (HPCV) mean value $(2.29 \%)$ indicates good quality of the flow cytometric assessments. Fluorescence histograms from the flow cytometer are presented in Fig. 1 to illustrate the accuracy of measurements with all internal standards used.

We found intraspecific genome size differences in most cases in which several populations were assessed, reaching $22.18 \%$ in the triploid T. kotschyi, $16.04 \%$ in the diploid T. parthenium, $9.43 \%$ in the tetraploid populations of $T$. aureum, $8.10 \%$ in the tetraploid T. polycephalum Sch. Bip., $1.89 \%$ in the hexaploid T. tabrisianum (Boiss.) Sons. \& Takht., and negligible variability $(<0.1 \%)$ among diploid T. pinnatum populations.

Genome size (2C) and total karyotype length (TKL) were significantly $(p<0.0001)$ and positively correlated with ploidy, but monoploid genome size $(1 \mathrm{Cx})$ did not decrease with ploidy. Nevertheless, when data of the same species at different ploidy levels was compared, there was a trend to genome downsizing i.e. reduction of monoploid genome size in T. polycephalum and T. pinnatum, whose
$4 \times$ and $6 \times$ polyploids present, respectively, $6.07 \%$ and $17.96 \%$ less genome size than expected from the genome size in their diploid populations. In addition, genome size is positively correlated with TKL $(p=0.003)$, with the number of rDNA signals $(p<0.0001)$ and with pollen morphometric characters such as polar axis $(p=0.03)$ and equatorial diameter $(p=0.02)$. Species with different compound inflorescences have significantly different genome sizes $(p=0.009)$; species with solitary capitula have the smallest genome compared to species presenting corymbs of capitula, which have the greatest amounts of DNA (5.54 pg vs $13.2 \mathrm{pg}$ at the diploid level).

\section{GC-rich regions}

Table 1 shows the results of fluorochrome banding with chromomycin and FISH assays, and Figs. 2 and 3 present selected representative Tanacetum metaphases. For the sake of clarity, only three chromosomal locations have been considered both for chromomycin $\mathrm{A}_{3}$ (CMA) and rDNA signals, following the treatment used in the www.plantrdnadatabase.com. These are: (peri)centromeric, interstitial and (sub)terminal. Results of chromomycin banding, which stains GC-rich DNA portions, are highly variable within and between Tanacetum species and even among individuals in some cases. In only four species is the number of bands always constant (the diploids T. parthenifolium Sch. Bip., T. persicum (Boiss.) Mozaff., T. pinnatum and T. budjnurdense (Rech.f.) Tzvelev) and low - four, see picture of $T$. pinnatum (Fig. 2a). However, from a minimum of two CMA+ bands in a wild population of the diploid T. parthenium (Fig. 3g) to a maximum of 66 bands for the diploid T. archibaldii Podlech (Fig. 3a) there are myriad variations. In most cases, however, there is a considerable range of variability within a species. The preferred position is usually (sub)terminal, and sometimes detached or terminal decondensed DNA (probably rDNA) is clearly seen with this staining (see Fig. 3k). Several species also present pericentromeric bands, and in two species (T. archibaldii and T. joharchii), several intercalary signals are also visible (Fig. 3a and 3k). Pericentromeric (and to a lesser extent, intercalary) bands appear in species that already present a high number of GC-rich bands.

Several taxa of different ploidy (different populations from T. aureum, T. heimerlii (Nábělek) Farsa, T. parthenium, T. polycephalum Sch. Bip. subsp. argyrophyllum (K.Koch) Podlech, T. pinnatum, T. sonbolii Mozaff. and T. tabrisianum) show odd numbers of bands in different individuals (Table 1). Intensity and size differences of chromomycin signals are clearly visible in several species, such as T. kotschyi (Fig. 2d), T. oligocephalum (DC.) Sch. Bip. (Fig. 2g), T. balsamita (Fig. 3c) and T. joharchii (Fig. 3k). 
Table 1 Provenance and voucher number from the Medicinal Plants and Drug Research Institute Herbarium (MPH), Shahid Beheshti University (Tehran) of the populations of Tanacetum studied, together with genome size, number of CMA+ bands and number of rDNA sites

\begin{tabular}{|c|c|c|c|c|c|c|c|c|c|c|}
\hline Species & Population & $\mathrm{PL}^{1}$ & $2 n^{2}$ & $2 \mathrm{C}^{3}$ & $2 C^{4}$ & $\mathrm{SD}^{5}$ & $1 C x^{6}$ & $\mathrm{HPCV}^{7}$ & $\mathrm{CMA}^{8}$ & rDNA $^{9}$ \\
\hline T. archibaldii Podl. & Mazandaran: Pole Zangoleh road (1790) & 2 & 18 & 8.77 & 8577 & 0.04 & 4.39 & 1.77 & 56itc $(50,54,66)$ & 4 \\
\hline T. balsamita L. & Mazandaran: Pole Zangooleh road (1788) & 2 & 18 & 10.38 & 10152 & 0.09 & 5.19 & 1.13 & $\begin{array}{l}40 \mathrm{tc}(24,30,34,36,40 \\
42,44)\end{array}$ & 4 \\
\hline T. budjnurdense (Rech.f) Tzvel. & Khorasan: Bujnourd (1477) & 2 & 18 & 10.13 & 9907 & 0.19 & 5.07 & 1.77 & $4 \mathrm{t}$ & 4 \\
\hline T. canescens DC. & Zanjan: Soltanieh (1912) & 2 & 18 & 9.3 & 9095 & 0.13 & 4.65 & 1.68 & 4,6 and $8 \mathrm{tc}$ & $6(8)$ \\
\hline $\begin{array}{l}\text { T. aureum (Lam.) Greuter, M.V.Agab. \& } \\
\text { Wagenitz }\end{array}$ & Urmia: Meyab (1848) & 4 & 36 & $17.08^{*}$ & 16704 & 1.38 & 4.27 & 2.62 & $28 \mathrm{tc}(26,32,34)$ & $10(8)$ \\
\hline $\begin{array}{l}\text { T. aureum (Lam.) Greuter, M.V.Agab. \& } \\
\text { Wagenitz }\end{array}$ & Urmia: Suluk Waterfall (1861) & 4 & 36 & $15.47^{*}$ & 15130 & 0.36 & 3.87 & 2.79 & 6 and $10 \mathrm{t}(3,4,5)$ & 10 \\
\hline T. heimerlii (Nabělek) Parsa & Urmia: Sero road, Golsheykhan (1227) & 2 & 18 & 8.25 & 8069 & 0.06 & 4.13 & 2.09 & $4 \mathrm{t}(2,3,5,6)$ & 4 and 6 \\
\hline T. oligocephalum (DC.) Sch.Bip. & Urmia: Chaldoran (1914) & 2 & 18 & 7.67 & 7501 & 0.05 & 3.84 & 2.53 & $6 t(4)$ & 6 \\
\hline T. oligocephalum (DC.) Sch.Bip. & Urmia: Naghadeh (1868) & 4 & 36 & $17.57^{*}$ & 17183 & 0.62 & 4.39 & 2.2 & $22 \mathrm{t}(10,12,14,20,24)$ & $12(8,10)$ \\
\hline T. oligocephalum (DC.) Sch.Bip. & Urmia: Mamakan (1911) & 4 & 36 & $14.87^{*}$ & 14543 & 0.28 & 3.72 & 3.02 & $10 t(8,9)$ & 10 \\
\hline T. fisherae Aitch. \& Hemsley. & Kerman Mehr mountain, north and east slopes (1916) & 5 & $44^{\mathrm{A}}$ & $17.11^{*}$ & 16734 & 0.27 & 3.42 & 2.69 & 30 tc $(8,14,22,24,28)$ & $\begin{array}{l}10(5,7,6,12 \\
15)\end{array}$ \\
\hline T. hololeucum (Bornm.) Podl. & Mazandaran: Pole Zangoleh road (1791) & 2 & 18 & 8.45 & 8264 & 0.2 & 4.23 & 1.61 & 14 and $16 \mathrm{t}(18,20,22)$ & 6 \\
\hline T. joharchii Sonboli \& Kaz.Osaloo & Khorasan, Chenaran, (1620) & 3 & 27 & $11.31^{*}$ & 11061 & 0.11 & 3.77 & 0.92 & 24itc (32 and 36) & $6(5,8)$ \\
\hline T. kotschyi (Boiss.) Grierson & Urmia, Anhar road, Suluk (1129) & 3 & 27 & $10.04^{*}$ & 9819 & 0.07 & 3.35 & 1.63 & $24 \mathrm{tc}(20,28,32,34)$ & 6 \\
\hline T. kotschyi (Boiss.) Grierson & Tabriz: Mishodagh (1339) & 3 & 27 & $10.72^{*}$ & 10484 & 0.12 & 3.57 & 1.83 & $44 \mathrm{tc}(28,32,42,44,48)$ & 6 \\
\hline T. kotschyi (Boiss.) Grierson & Zanjan: Ghidar (1419) & 3 & 27 & $8.58^{*}$ & 8391 & 0.09 & 2.86 & 1.89 & $18 \mathrm{tc}(20,22,26)$ & 4 \\
\hline T. parthenifolium (Willd.) Sch.Bip. & Urmia: Suluk Waterfall (1127) & 2 & 18 & 4.68 & 4577 & 0.09 & 2.34 & 3.07 & $4 \mathrm{t}$ & 4 \\
\hline T. parthenium (L.) Sch.Bip. & Tehran: Tochal (1483) & 2 & 18 & 3.84 & 3756 & 0.04 & 1.92 & 2.46 & $2 t(3,4)$ & $2(3,4)$ \\
\hline T. parthenium (L.) Sch.Bip. & $\begin{array}{l}\text { Tehran: Shahid Beheshti University, agricultural field of } \\
\text { research. Cultivated (1633) }\end{array}$ & 2 & 18 & 4.51 & 4411 & 0.04 & 2.26 & 3.06 & $14 \mathrm{tc}(8,10)$ & 6 \\
\hline T. parthenium (L.) Sch.Bip. & Hamadan: Dare Morad Beig (1903) & 2 & 18 & 4 & 3912 & 0.04 & 2.00 & 3.02 & $3 t(2,4)$ & $2(3,4)$ \\
\hline T. persicum (Boiss.) Mozaff. & Chahar Mahal \& Bakhtiari: Sabz Kuh (1502) & 2 & 18 & 4.4 & 4303 & 0.69 & 2.20 & 2.49 & $4 \mathrm{t}$ & 4 \\
\hline T. pinnatum Boiss. & Hamadan: Asad Abad (1895) & 2 & $18^{\mathrm{B}}$ & 13.19 & 12900 & 0.06 & 6.60 & 2.09 & $4 \mathrm{t}$ & 4 \\
\hline T. pinnatum Boiss. & Hamadan: Malayer (1896) & 2 & 18 & $13.18^{*}$ & 12890 & 0.08 & 6.59 & 2.75 & $4 t(6)$ & 4 \\
\hline T. pinnatum Boiss. & Hamadan: Razan (1894) & 4 & 36 & $24.87^{*}$ & 24323 & 0.58 & 4.15 & 1.45 & $6 \mathrm{t}(3,4,5)$ & 4 and 6 (8) \\
\hline $\begin{array}{l}\text { T. polycephalum Sch.Bip. ssp. argyrophyllum } \\
\text { (K.Koch) Podlech }\end{array}$ & Urmia: Meshkin Shahr (1884) & 2 & 18 & 9.26 & 9056 & 0.14 & 4.63 & 1.3 & $6 \mathrm{t}(5,7,8,10)$ & $6(7,8)$ \\
\hline T. polycephalum Sch.Bip. ssp. argyrophyllum & Urmia: Ghasemloo Valley (1866) & 4 & 36 & $17.88^{*}$ & 17487 & 0.84 & 4.47 & 2.84 & 8 and $10 t(5,6,13)$ & $12(14)$ \\
\hline
\end{tabular}


Table 1 Provenance and voucher number from the Medicinal Plants and Drug Research Institute Herbarium (MPH), Shahid Beheshti University (Tehran) of the populations of Tanacetum studied, together with genome size, number of CMA+ bands and number of rDNA sites (Continued)

\begin{tabular}{|c|c|c|c|c|c|c|c|c|c|c|}
\hline Species & Population & $\mathrm{PL}^{1}$ & $2 n^{2}$ & $2 \mathrm{C}^{3}$ & $2 C^{4}$ & $\mathrm{SD}^{5}$ & $1 C x^{6}$ & $\mathrm{HPCV}^{7}$ & $C M A^{8}$ & $\mathrm{rDNA}^{9}$ \\
\hline $\begin{array}{l}\text { T. polycephalum Sch.Bip. ssp. argyrophyllum } \\
\text { (K.Koch) Podlech }\end{array}$ & Urmia: Oshnaviyeh (1867) & 4 & 35 & $16.82^{*}$ & 16450 & 0.4 & 4.21 & 2.94 & $6,10,20$ and $24 t$ & $\begin{array}{l}14(10,11,12, \\
13,15)\end{array}$ \\
\hline $\begin{array}{l}\text { T. polycephalum Sch.Bip. ssp. argyrophyllum } \\
\text { (K.Koch) Podlech }\end{array}$ & Urmia: Marand (1856) & 4 & 36 & $17.89^{*}$ & 17496 & 0.16 & 4.47 & 2.4 & 32 and $36 t(8,20)$ & $12(14)$ \\
\hline $\begin{array}{l}\text { T. polycephalum Sch.Bip.ssp. azerbaijanicum } \\
\text { Podlech }\end{array}$ & Urmia: Ghishchi (1212) & 4 & 36 & $18.24^{*}$ & 17839 & 0.31 & 4.56 & 2.4 & $16 t(8,14)$ & 12 \\
\hline $\begin{array}{l}\text { T. polycephalum Sch.Bip. ssp. duderanum } \\
\text { (Boiss.) Podlech }\end{array}$ & Mazandaran: Pole Zangoleh road (1795) & 4 & 36 & $17.63^{*}$ & 17242 & 0.53 & 4.41 & 3.22 & $14 \mathrm{tc}(18,20,22,24)$ & $12(11)$ \\
\hline T. polycephalum Sch.Bip. ssp. farsicum Podlech & Hamadan: Kabudar Ahang (1901) & 6 & 54 & $24.12^{* *}$ & 23589 & 0.39 & 4.02 & 3.46 & 22 and $24 \mathrm{t}(18,20,26)$ & $13(14,17)$ \\
\hline $\begin{array}{l}\text { T. polycephalum Sch.Bip. ssp. heterophyllum } \\
\text { (Boiss.) Podlech }\end{array}$ & Mazandaran: Pole Zangoleh road (1797) & 4 & 36 & $18.10^{*}$ & 17702 & 0.29 & 4.53 & 2.48 & $\begin{array}{l}18 \text { and } 22 t(16,18,20, \\
30,32)\end{array}$ & $12(9,10,11)$ \\
\hline $\begin{array}{l}\text { T. polycephalum Sch.Bip.ssp. heterophyllum } \\
\text { (Boiss.) Podlech }\end{array}$ & Hamadan: Asad Abad (1899) & 6 & 54 & $22.99^{* *}$ & 22484 & 0.56 & 3.83 & 2.88 & $8 \mathrm{t}(10,12,14,16)$ & $18(15,16,17)$ \\
\hline T. sonbolii Mozaff. & (305) Urmia: Takab & 2 & 18 & 9.17 & 8968 & 0.19 & 4.59 & 2.12 & $5 t(4,6,8)$ & 8 \\
\hline T. tabrisianum (Boiss.) Sosn. \& Takht. & Urmia: Ahar (1905) & 6 & 54 & $23.56^{* *}$ & 23042 & 1.12 & 3.93 & 2.59 & 20 and $26 t(14,16,27)$ & $\begin{array}{l}14 \text { and } 16(10 \text {, } \\
12)\end{array}$ \\
\hline T. tabrisianum (Boiss.) Sosn. \& Takht. & Urmia: Ahar (1906) & 6 & 54 & $24.01^{* *}$ & 23482 & 0.16 & 4.00 & 1.96 & $50 t(28,40)$ & $16(14,15,26)$ \\
\hline T. tenuisectum (Boiss.) Podl. & Tehran: Damavand (863) & 2 & 18 & 7.68 & 7511 & 0.13 & 3.84 & 1.11 & 32,34 and $46 \mathrm{tc}$ & $6(8,10)$ \\
\hline T. tenuissimum (Trautv.) Grossh. & Urmia: Jolfa (1855) & 4 & 36 & $16.26^{*}$ & 15902 & 1.33 & 4.07 & 2.74 & 16 and 22 tc & 9 \\
\hline
\end{tabular}

All populations are native to Iran. (1) ploidy; (2) chromosome number; (3) genome size in pg; Petunia hybrida 'PxPC6' (2C = 2.85 pg), (*) Pisum sativum 'Express Long' (2C =8.37 pg), and (**) Triticum aestivum 'Chinese Spring' $(2 \mathrm{C}=30.9 \mathrm{pg}$ ) were used as internal standards; (4) genome size in Mbp (1 pg = 978 Mbp); (5) standard deviation; (6) monoploid genome size; (7) half peak coefficient of variation for each population; (8) most commonly found number of $\mathrm{CMA}+$ bands, together with the most usual position found for them ( $(=$ interstitial, $t=$ terminal or subterminal, $c=$ centromeric or pericentromeric); in brackets, other numbers of $\mathrm{CMA}+$ bands found; (9) most commonly found number of rDNA sites; in brackets other numbers of rDNA sites found (position of rDNA sites is always terminal or subterminal). ${ }^{A}$ The expected number for a pentaploid would

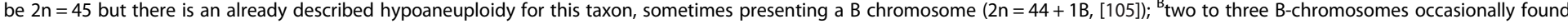



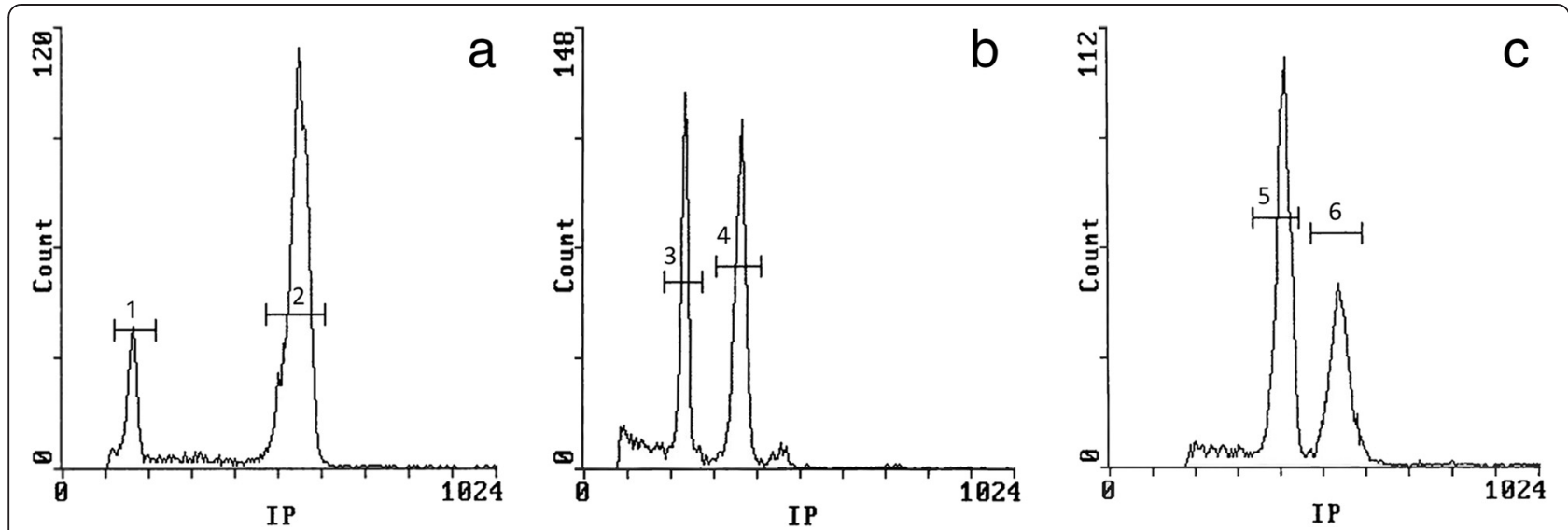

Fig. 1 Fluorescence histograms of the genome size assessments of (a) T. heimerlii $2 x$ population (2) with Petunia hybrida (1) as internal standard, (b) T. pinnatum 4x population (4) with Pisum sativum (3) as internal standard and (c) T. polycephalum ssp. heterophyllum 6x population (5) with Triticum aestivum (6) as internal standard

There is no significant relationship between ploidy and the most commonly found number of signals for a given species, nor with genome size. In addition, the number of GC-rich bands is positively correlated with the altitude at which species occur, considering all taxa $(p=0.04)$ and only diploids $(p=0.006)$.

\section{rDNA loci}

The FISH assays of a large sample representing genus Tanacetum show a totally homogeneous L-type organisation of ribosomal RNA genes. The number of signals within a species (even within a population) and between species at the same ploidy is usually heterogeneous although not as heterogeneous as the number of CMA+ bands. The minimum number of signals found was two (one locus) for one population of T. parthenium and the maximum was 26 (13 loci) for some individuals of one population of T. tabrisianum (although most T. tabrisianum had eight loci, see Fig. 2n). In all cases, rDNA signals occupied terminal or subterminal positions, always coincidental with $\mathrm{CMA}+$ signals, and sometimes appearing as decondensed (as T. joharchii in Fig. 3d, 1 arrows). Species such as T. fisherae and T. tabrisianum (Fig. 2k, n, asterisks), presented locus size differences, but in general, this was homogeneous. The number of rDNA signals was positively and significantly correlated with ploidy and genome size ( $p<0.0001$ for both), but there was no reduction in number of loci, as the number of signals per haploid genome did not diminish significantly with increasing ploidy. However, a reduction in the number of signals was detected in individual polyploid series for $T$. pinnatum and three out of four of T. polycephalum. In all other cases there was additivity; that is, the tetraploid had exactly twice as many signals as the diploid, except in the case of one tetraploid $T$. polycephalum population, in which there was upsizing by one locus.
The heterogeneity in the number of signals for a given species (that is, the different number of rDNA loci that could be found in metaphases coming from the same species) was positively correlated with ploidy $(p<0.0001)$ which means that with increasing ploidy there was a tendency to instability in the number of rDNA signals. In particular, the hypoaneuploid T. fisherae $(2 \mathrm{n}=5 \mathrm{x}=44)$ and T. polycephalum var. argyrophyllum $(2 \mathrm{n}=4 \mathrm{x}=35)$ were the most unstable with respect to the number of rDNA signals.

\section{Phylogenetic relationships among species and ancestral characters}

Statistical analyses at the genus level should consider phylogenetic relationships among taxa to be as unbiased as possible. However, due to lack of enough data, these comparisons could not be done in most cases. Still, we detected significant and positive correlations using the phylogenetic generalised least squares method (PGLS) between genome size $(2 \mathrm{C})$, ploidy, and number of rDNA signals $(p<0.0001)$, i.e. all parameters increase/decrease in concert. The reconstruction of character evolution into the phylogeny (Fig. 4), based on diploid taxa, provides ancestral $2 \mathrm{C}$ values ranging from 7.98 to $8.84 \mathrm{pg}$, from 10 to 13 for CMA+ bands, and from 4 to 6 rDNA signals for Tanacetum species.

\section{Discussion}

All species investigated present $\mathrm{x}=9$ as the basic chromosome number confirming previous research [20, 23]. In contrast to other Anthemideae, in which other basic chromosome numbers have been found (e.g. Artemisia presents $\mathrm{x}=7,8,9,10$, 11; Pentzia Thunb., $\mathrm{x}=7,8,9$, Lasiospermum Fisch., $\mathrm{x}=9,10$ [40]) $\mathrm{x}=9$ it is the only found in Tanacetum until present [41]. 


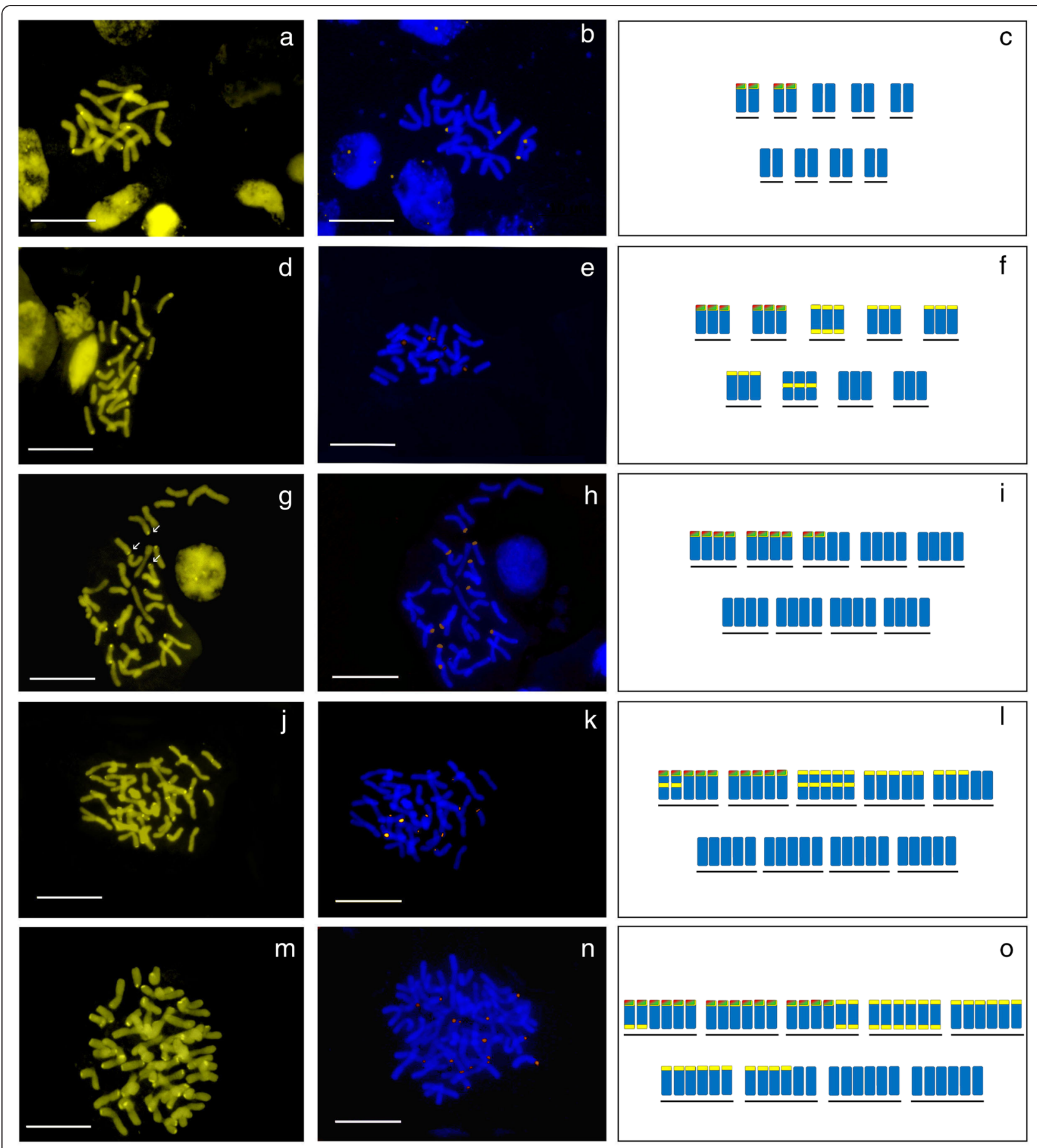

Fig. 2 Chromomycin $\mathrm{A}_{3}$-positive (CMA+) and FISH images of the most commonly found metaphases of representative species of each ploidy level in Tanacetum. CMA+ bands are marked yellow, 26S-5S rDNA signals, marked orange in images. CMA+ positive bands are marked yellow, 26S-5S rDNA signals, are marked red-green in the schematic representation of chromosomes. (a, b, c) Tanacetum pinnatum, 2x population (Asad Abad, 1895) showing four CMA+ and four rDNA signals; (d, e, f) T. kotschyii, 3x population (Urmia, 1129) showing up to 24 CMA and six rDNA signals; large CMA+ bands indicated with asterisks; (g, h, i) T. oligocephalum, 4x population (Mamakan, 1911), showing 10 CMA+ and 10 rDNA signals; large CMA+ bands indicated with asterisks and faint bands indicated with arrows; (j, $\mathbf{k}, \mathbf{I})$ T. fisherae, 5x population, showing up to $30 \mathrm{CMA}+$ and 10 rDNA signals; large rDNA signals indicated with asterisks; (m, n, o) T. tabrisianum 6x population (Ahar, 1906), showing up to 50 CMA+ and 16 rDNA signals; large rDNA signals indicated with asterisks. Scale bars $=10 \mu \mathrm{m}$ 

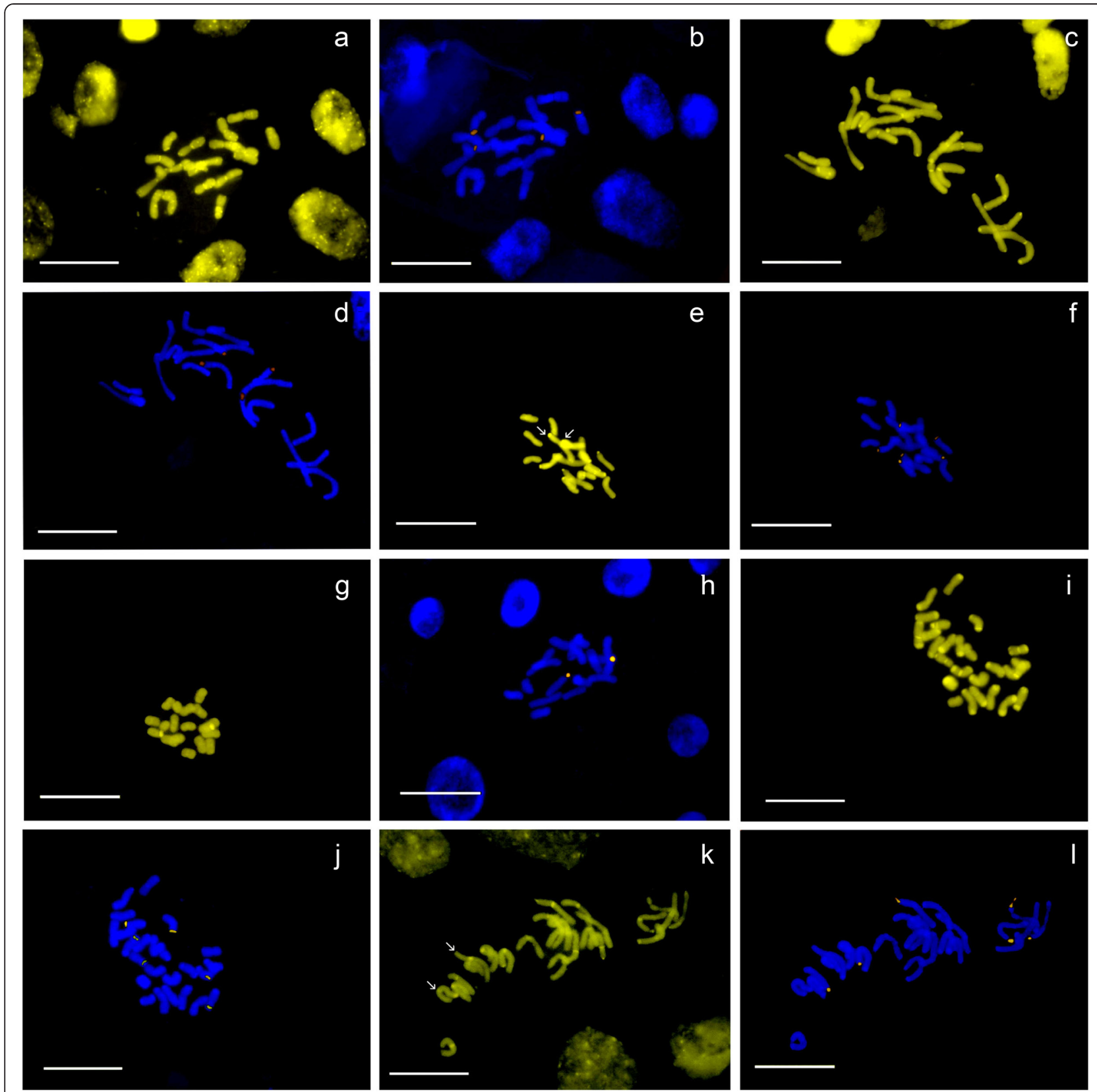

Fig. 3 Chromomycin $\mathrm{A}_{3}$-positive (CMA+) FISH images of cytogenetically variable Tanacetum species, in which CMA+ bands are marked yellow, 26S-5S rDNA signals and marked orange. (a, b) T. archibaldii (2x) with 56 CMA signals (asterisks indicate interacalary CMA+ bands) and with 4 rDNA signals; (c, d) T. balsamita, 2x, with 40 CMA+ signals (many of them pericentromeric, indicated with asterisks) and with four rDNA signals a slightly decondensed rDNA is indicated with an arrow; cultivated $(\mathbf{e}, \mathbf{f})$ and wild $(\mathbf{g}, \mathbf{h})$ T. parthenium (from Shahid Beheshti University, 1633 and Tochal, 1483, respectively), both 2x with 14 and six CMA+ and six and two rDNA signals observed, respectively; (i, j) T. kotschyi (Tabriz, Mishodagh, 1339), 3x, with 44 CMA+ signals and six rDNA signals and (k, l) T. joharchii, 3x, with 24 CMA and six rDNA signals; note faint or interstitial CMA+ bands indicated with asterisks and decondensed rDNAs indicated with arrows in both pictures. Scale bars $=10 \mu \mathrm{m}$

To our knowledge, genome size was available for only four species of the genus, the diploid T. vulgare (mean $2 \mathrm{C}$ $=8.85 \mathrm{pg}$, [37]), a tetraploid population of T. cinerariifolium (Trevir.) Sch. Bip. $(2 \mathrm{C}=14.53 \mathrm{pg}$, [38] $)$ and some hexaploid populations of T. balsamita and T. corymbosum
(L.) Sch. Bip. $(2 \mathrm{C}=21.44 \mathrm{pg}$ and $2 \mathrm{C}=19.95 \mathrm{pg}$, respectively, [39]). Therefore this research contributes new genome sizes for all species and subspecies studied here (with the exception of $T$. balsamita), representing approximately $11 \%$ of the recognised species of the genus. The 


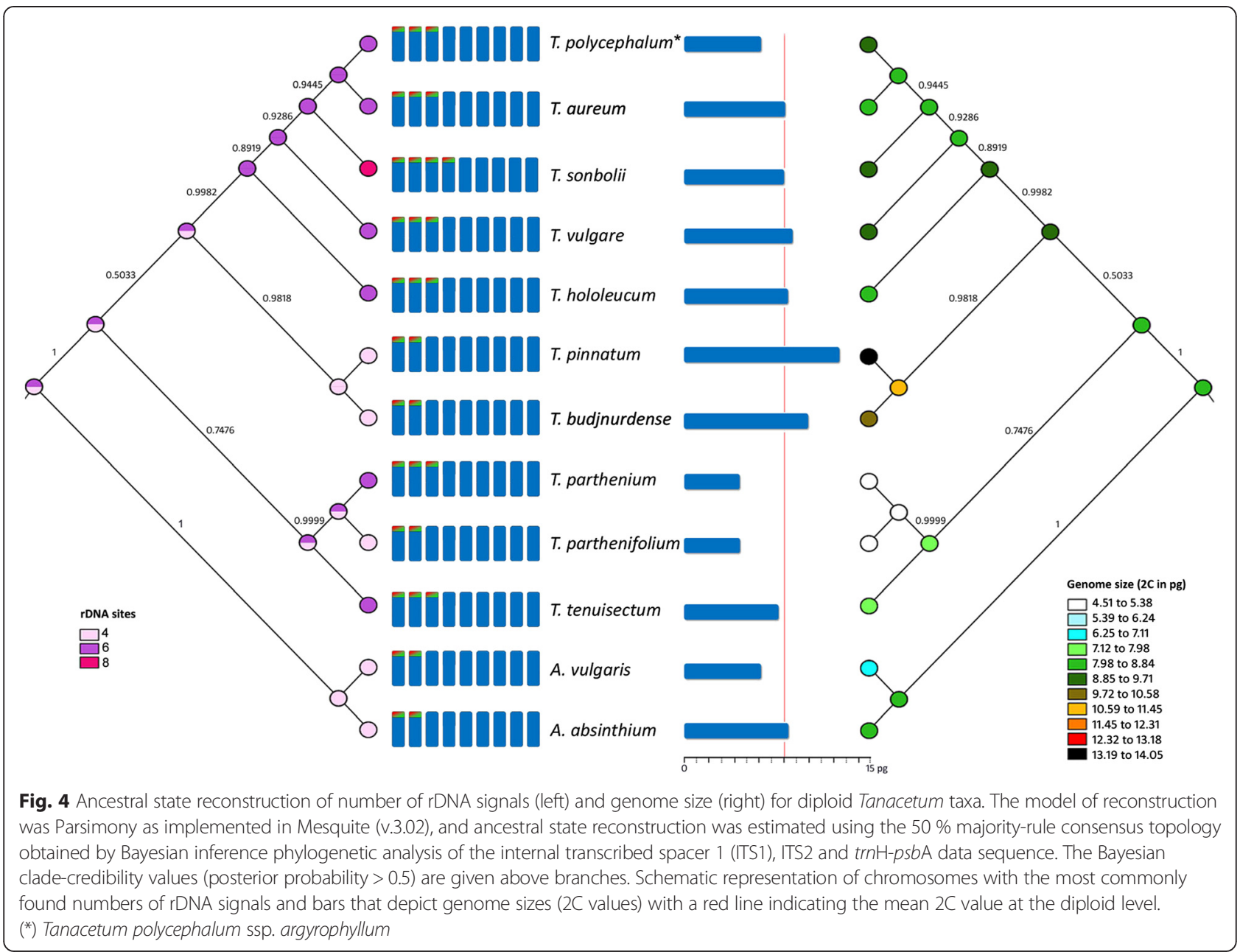

amount of nuclear DNA is mostly intermediate in Tanacetum. According to the genome size categories in plants established by [42], three of the 20 species we studied $(17.65 \%)$ have small genome sizes $(2.8 \leq 2 \mathrm{C}<7 \mathrm{pg})$, whereas the remaining have intermediate genome sizes $(7 \leq 2 \mathrm{C}<28 \mathrm{pg})$, including all ploidy levels. Mean genome size of the diploid taxa studied $(8.35 \mathrm{pg})$ was coincidental with the mean of the tribe Anthemideae $(8.30 \mathrm{pg})$ and of the family Asteraceae $(2 \mathrm{C}=8.20 \mathrm{pg})$, according to data from the Genome Size in Asteraceae Database (www.asteraceaegenomesize.com). Closely related diploid genera, such as Artemisia, have similar mean genome sizes $(2 \mathrm{C}=7.75 \mathrm{pg})$ whereas the majority of diploid Tanacetum allies present remarkably lower mean $2 \mathrm{C}$ values $(2 \mathrm{C}=5.9 \mathrm{pg}$ for Achillea, $2 \mathrm{C}=6.4 \mathrm{pg}$ for Anacyclus L., 2C $=5.12$ for Anthemis, 2C $=5.71$ for Matricaria L., 2C=5.13 for Tripleurospermum). The comparatively larger mean genome size of Tanacetum could be because our sample lacks annual representatives (as does most of the genus) which, quite often though not always - tend to present lower genome sizes than their counterparts [43].

\section{Genome downsizing and polyploidy in Tanacetum}

Polyploidy and hybridisation are important evolutionary forces shaping plant genomes and underlying the huge angiosperm diversity. Both can confer evolutionary advantages [44-46] attributed to the plasticity of plant genomes and to increased genetic variability, generating individuals capable of exploiting new niches [47]. Polyploidy is linked to numerous epigenetic/genomic changes such as chromo some rearrangements, transposable element mobilisation, gene silencing or genome downsizing [48-50]. Certainly, genome downsizing would be a widespread biological response to polyploidisation [51]. This may lead to diploidisation of the polyploid genome [52-54]. There is no evidence of genome downsizing across Tanacetum ploidy levels. However, there are genome size trends within separately polyploid series of particular species. Tetraploid T. pinnatum presents up to $6.07 \%$ lower $1 C x$ than expected from the $1 \mathrm{Cx}$ of the diploid populations, and hexaploid and tetraploid $T$. polycephalum present, respectively, $17.96 \%$ and $4.28 \%$ lower $1 \mathrm{Cx}$ than expected from the $1 \mathrm{Cx}$ of the diploid population. This is consistent with previous observations of more pronounced genome 
downsizing with higher ploidy [30, 45, 55-57]. Recent work [57] has demonstrated erosion of low copy-number repetitive DNA in allopolyploids, sometimes counteracted by expansion of a few repeat types. Age and genomic similarity of the parental genome donors of the polyploids play a role in the extent of genome size change with polyploidy [56] and a deeper understanding of the likely hybridogenic origin of some of the Tanacetum polyploids studied would allow more robust hypotheses on the balancing genomic processes these taxa may have undergone.

\section{Small genome size and invasiveness}

Tanacetum parthenium appears listed in several countries as an invasive weed [58, 59]. Its genome size was the smallest obtained in our study (three populations were analysed whose mean was $2 \mathrm{C}=4.12 \mathrm{pg}$ ). This is consistent with previous findings [60], which detected that many weeds (including those in family Asteraceae) had smaller amounts of DNA than closely related (nonweedy) species. This relationship is supported by recent work $[61,62]$. The other species with small genome sizes in our sample ( $T$. parthenifolium and $T$. persicum) have not, however, been recorded as weeds. Therefore a small genome size (particularly, smaller than that of closely related species) is a necessary but not sufficient condition for a plant to become a weed. A recent review [63] concluded that invasive species were characterised by small and very small genomes, yet this conclusion may be biased by the general trend of land plants to small genome sizes as a whole [42].

\section{Intraspecific instability and massive amplification of GC-rich DNA occur in several Tanacetum species}

We found that ribosomal DNA is always CMA+ in Tanacetum (see Discussion on rDNA loci below), common to other studies [45, 64, 65] although exceptions are found [66]. For most of the studied populations, the number of CMA+ bands significantly exceeded that of rDNA signals and there was no apparent relationship with ploidy or with genome size (Table 1 ). The number of CMA+ bands is neither stable within a species nor within a population. The presence of odd and of nonhomologous signals was occasionally observed, for example in T. aureum and in T. oligocephalum (Table 1), where a single chromosome with two CMA+ bands at each end was observed instead of the two identical chromosomes expected. Odd ploidy species, such as $T$. fisherae (5x) and T. kotschyi (3x), were particularly labile with respect to the number of CMA+ bands. However, the greatest variability in number of CMA+ bands corresponded to the diploid T. balsamita, in which sevendifferent numbers of signals were found (Table 1 and Fig. 3c). Such instability in the number of GC-rich bands was unexpected and has seldom been reported. Only the highly variable CMA+ banding pattern previously found in Citrus L. and close genera [67] is similar to the variability found in Tanacetum, probably as a consequence of amplification or reduction in satellite sequences known to be particularly GC-rich [68]. It is possible that some as yet undescribed satellite DNA type, specific to Tanacetum, is in part responsible for these karyotype features.

Another characteristic of the CMA+ banding pattern in Tanacetum was the striking number of signals found in certain species, particularly in diploid taxa (Table 1, Fig. 3a, $3 \mathrm{c}, 3 \mathrm{i}, 3 \mathrm{k})$. This contrasts with previous work on genus $\mathrm{Ar}$ temisia $[69,70]$, in which a large number of CMA+ bands was only detected in some polyploids, while the only $\mathrm{CMA}+$ bands in diploids were those exactly corresponding to rDNA loci. In other Asteraceae genera, such as Cheirolophus Cass., a large number of CMA+ bands was also reported, mostly coincidental with 35S rDNA signals [71]; this was also the case for Filifolium [72]. In Centaurea L. [73] the number of CMA+ bands was the same as or smaller than the number of $35 \mathrm{~S}$ rDNA signals, while in some Xeranthemum L. [74], Galinsoga Ruiz \& Pav. and Chaptalia Vent. [75], few additional GC-rich bands were observed.

While most bands are in terminal position, pericentromeric GC-rich heterochromatin was detected in several species, some of them closely related, such as T. polycephalum, T. aureum and T. canescens DC. on one hand (Table 1), and T. fisherae (Fig. 2j), T. kotschyi (Fig. 2d), T. tenuisectum Sch.Bip. and T. joharchii (Fig. 3k) on the other. In fact, in Arabidopsis thaliana (L.) Heynh., centromeres are one of the most GC-rich genomic regions [76]. Differences in total GC\% among eukaryotes are largely driven by the composition of non-coding DNA of which retrotransposons are the most abundant (for example, LTR Huck elements contain more than 60 \% GC, [77]). Possibly, some centromere-specific LTR could have undergone amplification in these closely related Tanacetum genomes.

What can this fluctuating distribution of CMA+ bands mean, and what are the implications? It is feasible that a specific satellite and/or retroelement family may be expanded or contracted in Tanacetum genomes. Although the number and the distribution of $\mathrm{CMA}+$ bands are thought to be relatively constant features of plant karyotypes [24, 70], our results strongly argue against this view, since variability was found even within a population. In addition, there were few evident ecological or geographic patterns in Tanacetum, that is, few significant relationships were found between the number or variability of GC-rich signals and geographical distribution, weedy behaviour, or soil features. The only significant association is with altitude: Tanacetum species living at higher altitudes tend to present more GC-rich DNA. In line with this hypothesis, [78] found a large number of heterochromatic bands (both GC- and AT-rich) in species from the 
Asteraceae genus Myopordon Boiss. inhabiting high mountain areas. These authors related the development of such heterochromatic bands in terminal regions with an adaptation to protect telomere function from UV radiation, a major genome-damaging agent, particularly in high mountains. Heterochromatin expansion in terminal regions (as in Tanacetum) has also been suggested to enhance chromosomal pairing during cell division [79].

\section{Genomic organisation of rDNA and typical distribution pattern of Tanacetum}

Our cytogenetic study confirmed that both the $5 \mathrm{~S}$ and the 35S rRNA genes are co-localised (L-type arrangement) in all chromosomes. Such organisation was found in Artemisia for the first time in higher plants [36], and subsequently inferred for at least $25 \%$ of Asteraceae species [25]. In the latter study, Southern blot hybridisation was performed on a sample of $T$. parthenium, and the profile obtained also suggested L-type organisation for its rDNA. Prior to our study, the only evidence of this particular rDNA organisation directly in chromosomes was from $T$. achilleifolium and T. parthenium [35]. Curiously, these authors found one unlinked $5 \mathrm{~S}$ locus additional to two regular L-type loci in T. achilleifolium, while $T$. parthenium showed L-type arrangement in all loci. Within the sample studied we could not find a single species with unhomogenised rDNA (i.e. that both kinds of rDNA arrangement, linked and separated, were present in the same species), since both rDNA probes invariably overlapped in all loci. Nevertheless, possible incomplete homogenisation of rRNA genes may also be present in other close genera such as Achillea and Chrysanthemum L. [72, 80]. Besides, in some metaphases decondensed rDNA signals are detected. These probably correspond to active nucleolar organizer regions (NORs), i.e. rDNA that is being actively transcribed, visible in $T$. balsamita (Fig. 3d, one signal) and in T. joharchi (Fig. 3l, two signals). Decondensed rDNA, however, is not always detected during metaphase.

\section{Unexpected variation in number of rDNA loci}

The number of rDNA signals was always smaller and less variable than that of CMA+ bands, as found previously in other closely related species (in Artemisia, [45, 70]) and even in other families (genus Ipomoea from Convolvulaceae, [81]). In particular, the most common number of rDNA loci at the diploid (with two to three loci) and tetraploid (with five to six loci) levels was relatively constant and consistent with previous data for Tanacetum $[35,82]$ or for the closely related genera Matricaria and Tripleurospermum [25]. However, taxa with odd, higher ploidy or aneuploid levels often displayed higher intraspecific polymorphism in the number of signals. Of these, the hypoaneuploid population of $T$. polycephalum var. argyrophyllum was particularly striking, since metaphases with $10,11,12,13,14$ and 15 rDNA signals were observed; the hypoaneuploid $T$. fisherae $(2 \mathrm{n}=5 \mathrm{x}=44)$ showed a similar condition (Table 1). Thus, processes of hypoaneuploidy could affect genomic stability producing this variation in number of loci.

Although it would be expected that the number of signals remain relatively constant for a given species, cases of intraspecific polymorphism in the number of signals are increasingly reported. As for Tanacetum, diversity in the number of rDNA signals for a given species has been found in Fragaria vesca L. [26] and in Phaseolus vulgaris L. [83], for example. However, what is exceptional in Tanacetum is that these polymorphisms happen even at the population level and, albeit very rarely, sometimes within the same individual. All this, together with the unexceptional situation of odd numbers of signals in many taxa (which otherwise is rare) illustrates how dynamic Tanacetum genomes are.

Given these fluctuations, the constantly terminal position of rDNA signals in all the species studied could be considered surprising. However, this is so in most plants: [84] argued that there seems to be a strong positive selection favouring the location of $35 \mathrm{~S}$ rDNA at chromosome ends, probably as a result of homologous recombination constraints.

As with the number of CMA+ bands, there was no global reduction in the number of signals per haploid genome with increasing ploidy. Similarly, the number of rDNA loci did not show any apparent relationship with genome size.

Our analyses have allowed us to distinguish some interesting relationships between several of the traits studied. As others have found $[85,86]$ morphological data regarding pollen size are tightly linked with genome size in Tanacetum, i.e. pollen size reflects genome size in this genus. In addition, species of Tanacetum with solitary capitula have smaller genome sizes than those with capitula organised in complex inflorescences. It is known that sometimes polyploids tend to present larger reproductive organs and more flowers per inflorescence than their diploid relatives [87], but few studies have approached the relationship of genome size or polyploidy with natural patterns, such as inflorescence architecture [88]. Suggested that the shift in inflorescence phyllotaxis from spiral to distichous would have occurred at the same time as the expansion of genome size characterising several groups of grasses [89], though admitting no clear reason why genome size as such should affect inflorescence architecture.

In addition, the reconstruction of ancestral cytogenetic traits brings evidence that these characters have followed increases and decreases during evolution in Tanacetum (Fig. 4). In general, it seems that genome size and the number of rDNA loci have increased, while the number 
of CMA+ bands has decreased in most present taxa. Few studies have specifically approached the evolution of cytogenetic traits within a temporal and phylogenetic perspective and, while events favouring increase in genome size and number of rDNA signals during evolution have been detected [56], there is no discernible pattern in the direction of these changes. For example, [90] found a decrease in number of rDNA loci during the evolution of Hypochaeris L. The overall decrease of GC-rich DNA could also respond to depletion of certain repeated DNA sequences during evolution in Tanacetum.

\section{Conclusions}

This work is the first extensive cytogenetic report on Tanacetum species. We have confirmed linkage of both rDNAs in all chromosomal loci. Tanacetum stands out as variable, particularly in the number of rDNA sites and CMA + bands. These vary widely even within a given population. In particular, aneuploid and odd ploidy taxa appear more unstable. The observed intrapopulation differences are likely a reflection of genomic differentiation which could complement further population biology studies. Besides, the number of GC-rich DNA bands found in certain species is striking and deserves more study. A possible cause is the amplification of repeat families or TEs in these species compared to others showing utterly different profiles. Polyploidy and aneuploidy are important evolutionary forces in this genus. Several of the studied populations present spontaneous mixed ploidy, another sign of its current genomic dynamism.

It is difficult to set general patterns in the evolution of genome size, number of rDNA loci or heterochromatin in plants. Yet, studies such as ours contribute to the knowledge of these cytogenetic features at a larger scale. Finally, the particularly labile cytogenetic scenario observed in Tanacetum is uncommon and has been seldom reported. Both chromosomal markers (rDNA loci and GC-rich bands) tend to be relatively constant at the species level, a feature that has allowed their use in biosystematics. Still, even at the population level, these traits can be variable in Tanacetum and this variation is better understood considering evolutionary relationships between species.

\section{Methods}

\section{Plant materials}

Seeds of 38 populations of Tanacetum species were collected from the wild for molecular cytogenetics and genome size assessments (Table 1). Specimen vouchers of the studied materials have been deposited at the Medicinal Plants and Drug Research Institute Herbarium (MPH) of the Shahid Beheshti University, Tehran.

\section{Chromosome preparations}

Root tip meristems were obtained by germinating achenes on moist filter paper in Petri dishes at room temperature in the dark. They were pre-treated with $2 \mathrm{mM} \mathrm{8-}$ hydroxyquinoline at room temperature for 3-3.5 h. Subsequently, the material was fixed in $3: 1 \mathrm{v} / \mathrm{v}$ absolute ethanol:glacial acetic acid and stored at $4{ }^{\circ} \mathrm{C}$ for $24 \mathrm{~h}$, and then stored in $70 \%$ ethanol at $4{ }^{\circ} \mathrm{C}$ until use. For fluorochrome banding and fluorescence in situ hybridisation (FISH), the chromosome spreads were obtained using the air-drying technique of [91], with modifications. Fixed root tips were washed three times in distilled water with shaking and later in citrate buffer $(0.01 \mathrm{M}$ citric acid-sodium citrate, $\mathrm{pH}$ 4.6) for $30 \mathrm{~min}$, excised and incubated for 20-35 $\mathrm{min}$ at $37{ }^{\circ} \mathrm{C}$ in an enzymatic mixture [ $4 \%$ cellulase Onozuka R10 (Yakult Honsha), 1 \% pectolyase Y23 (Sigma) and 4\% hemicellulase (Sigma)]. Digested root tips were placed on a slide, excess enzymatic solution was removed and protoplasts were obtained by applying gentle pressure in a drop of $45 \%$ acetic acid. The metaphase plates were evaluated using a phase contrast microscope and slides were frozen for at least $24 \mathrm{~h}$ at $-80{ }^{\circ} \mathrm{C}$. Later, the coverslip was quickly removed, the slide rinsed with absolute ethanol and then air dried for at least two days protected from dust.

\section{Fluorochrome banding}

In order to reveal GC-rich bands, the chromosomes were stained with the fluorochrome chromomycin $\mathrm{A}_{3}$ (CMA), according to $[24,92]$ with slight modifications. The slides were incubated in Mcllvaine buffer $\mathrm{pH} 7$, $\mathrm{MgSO}_{4}(0.1 \mathrm{~g} / \mathrm{L}$ in Mcllvaine buffer, $\mathrm{pH}$ 7) for $15 \mathrm{~min}$, stained with $\mathrm{CMA}_{3}(0.2 \mathrm{mg} / \mathrm{ml}$ in McIlvaine buffer $\mathrm{pH} 7$ $\mathrm{MgSO}_{4}$ ) for $90 \mathrm{~min}$ in the dark, rinsed in Mcllvaine buffer $\mathrm{pH} 7$, and counterstained with methyl green $(0.1 \%$ in McIlvaine buffer $\mathrm{pH}$ 5.5) for $10 \mathrm{~min}$; rinsed in Mcllvaine buffer $\mathrm{pH} 5.5$, dried briefly at room temperature, also in the dark, and mounted in two small drops of Citifluor AF1 (glycerol/PBS solution).

\section{Labelling of rDNA probes and FISH}

For hybridisation experiments we mostly used the same slides as for fluorochrome banding with CMA after destaining with fixative, dehydration through an ethanol series $(70 \%, 90 \%$ and $100 \%)$ and drying for two days. The probe used for 35S rDNA localisation was a plasmid carrying a $2.5 \mathrm{~kb}$ insert of $26 \mathrm{~S}$ rRNA gene from Lycopersicum esculentum Mill. labelled with Cy3 (Jena Biosciences) using the Nick Translation Mix (Roche). The 5S rDNA probe was an approximately $0.7 \mathrm{~kb}$-long trimer of $5 \mathrm{~S}$ rRNA genes from Artemisia tridentata Nutt., labelled with Green dUTP using the Nick Translation Mix (Abbott Molecular). This probe contained three units of the $5 \mathrm{~S}$ rRNA gene (120 bp) and the non-coding intergenic spacers (about $290 \mathrm{bp}$ ). Both probes have been used 
following previous research [25, 65]. FISH was carried out according to [24] with slight modifications. Slides were incubated in $100 \mu \mathrm{g} / \mathrm{ml}$ DNase-free RNase in $2 \times \mathrm{SSC}$ (0.03 $\mathrm{M}$ sodium citrate and $0.3 \mathrm{M}$ sodium chloride) for 1 $\mathrm{h}$ at $37{ }^{\circ} \mathrm{C}$, washed in $2 \mathrm{xSSC}$ three times for $5 \mathrm{~min}$ with slow shaking, rinsed in $0.01 \mathrm{~N} \mathrm{HCl}$ for 2 min and incubated in pepsin $(0.1 \mathrm{mg} / \mathrm{ml}$ in $0.01 \mathrm{~N} \mathrm{HCl})$ for $15 \mathrm{~min}$ at $37{ }^{\circ} \mathrm{C}$, washed in $2 \mathrm{xSSC}$ for 5 min twice, dehydrated in an ethanol series (70 \%, $90 \%$ and $100 \%$, for $3 \mathrm{~min}$ in each) and air dried. The probe hybridisation mixture contained 25-100 ng/ $\mu \mathrm{l} \mathrm{rDNA}$ probes, formamide, $50 \%$ (w/v) dextran sulphate, and $20 \times$ SSC. This was denatured at $75{ }^{\circ} \mathrm{C}$ for $10 \mathrm{~min}$ and chilled on ice for $5 \mathrm{~min}$. A volume of $30 \mu \mathrm{l}$ was loaded onto slides and covered with plastic coverslips. The preparations were denatured at $75^{\circ} \mathrm{C}$ for $10 \mathrm{~min}$ and transferred at $55^{\circ} \mathrm{C}$ for $5 \mathrm{~min}$. Hybridisation was carried out for more than $18 \mathrm{~h}$ at $37^{\circ} \mathrm{C}$ in a humidified chamber. Following hybridisation, the slides were washed with shaking in $2 \times$ SSC, $0.1 \times$ SSC and $2 \times \mathrm{SSC}$ at $42{ }^{\circ} \mathrm{C}$ for $5 \mathrm{~min}$ twice each, and then once in $2 \times \mathrm{SSC}$ for $5 \mathrm{~min}$, once in $4 \times$ SSCT for 7 min, briefly rinsed in $1 \times$ PBS and dried.

Samples were counterstained with Vectashield (Vector Laboratories, Inc., Burlingame, CA, USA), a mounting medium containing $500 \mathrm{ng} / \mu \mathrm{l}$ of 4,6-diamidino-2-phenylindole (DAPI). The fluorescence signals were analysed and photographed using a digital camera (AxioCam HRm, Zeiss) coupled to a Zeiss Axioplan microscope; images were analysed with Axiovision HR Rev3, version 4.8 (Zeiss) and processed for colour balance, contrast and brightness uniformity in Adobe Photoshop. A minimum of 10 metaphase plates per population were analysed. Graphics were assembled with PowerPoint 2010 (Microsoft). The data were submitted to the Plant rDNA database, a database compiling information on rDNA signal number, position and organisation [93, 94].

\section{Flow cytometric measurements}

For flow cytometric measurements of leaf tissue, seedlings were obtained from seeds grown in pots in the greenhouse of the Faculty of Pharmacy, University of Barcelona. Five individuals per population of the different Tanacetum species were studied, and of these, two samples of each were individually processed. Petunia hybrida Vilm. 'PxPc6' $(2 \mathrm{C}=2.85 \mathrm{pg})$, Pisum sativum L. 'Express Long' $(2 \mathrm{C}=8.37 \mathrm{pg})$ and Triticum aestivum $\mathrm{L}$. 'Chinese Spring' ( $2 \mathrm{C}=30.9 \mathrm{pg})$ from [95] were used as the internal standards. Fresh leaf tissue for the standard and the target species were chopped up together in $600 \mu \mathrm{l}$ of LB01 buffer (8 \% Triton X-100; [96]) supplemented with $100 \mu \mathrm{g} / \mathrm{ml}$ ribonuclease A (RNase A, Boehringer, Meylan, France) and stained with $36 \mu \mathrm{l} \mathrm{of} 1 \mathrm{mg} / \mathrm{ml}$ propidium iodide (Sigma-Aldrich, Alcobendas, Madrid, $60 \mu \mathrm{g} / \mathrm{ml}$ ) to a final concentration of $60 \mu \mathrm{g} / \mathrm{ml}$, and kept on ice for 20 min. The fluorescence measurements were performed using an Epics XL flow cytometer (Coulter Corporation, Miami, FL, USA) at the Centres Científics i Tecnològics, University of Barcelona. More details about the method are in [55]. The data have been submitted to the GSAD (Genome Size in Asteraceae Database) $[97,98]$.

\section{Phylogenetic analyses and reconstruction of character evolution}

The nuclear ITS1 + ITS2 and chloroplast trnH-psbA sequences (listed in Additional file 1) were edited by BioEdit v. 7.1.3.0 [99] followed by manual adjustment. Artemisia taxa were considered as outgroups [3]. All taxa used for the phylogenetic analysis were diploid in order to avoid the effect of polyploidy in the estimated nuclear DNA contents, number of rDNA sites or GC-rich bands. Bayesian phylogenetic analysis was performed in MrBayes 3.1.2 [100] using a SYM + G model determined from jModeltest v. 2.1.3 [101] under the Akaike information criterion (AIC; [102]), to ascertain phylogenetic relationships. The Markov chain Monte Carlo (MCMC) sampling approach was used to calculate posterior probabilities (PPs). Four consecutive MCMC computations were run for 2,000,000 generations, with tree sampling every 100 generations. Data from the first 1000 generations were discarded as the burn-in period. PPs were estimated through the construction of a $50 \%$ majority-rule consensus tree.

The ancestral character reconstructions (genome size, number of rDNA sites and number of CMA+ bands) were conducted using unordered maximum parsimony as implemented for continuous and meristic characters in Mesquite v. 3.02 software [103] using the $50 \%$ majority-rule consensus tree resulting from the Bayesian inference analysis as the input tree file. The output trees were edited with Mesquite v. 3.02.

\section{Statistical analyses}

Analyses of regression, one-way ANOVA, $X^{2}$, ShapiroWilk test for normality and Barlett's test for equality of variances were performed with RStudio, v.0.98.1078. In addition, the phylogenetic generalised least squares (PGLS) algorithm as implemented in the nlme package for R (Version 3.1-118) was used to analyse variation of genome size, number of rDNA sites and number of $\mathrm{CMA}+$ bands in a phylogenetic context. Data on genome size and ribosomal DNA loci for the complementary and outgroup species were extracted from the Plant rDNA database [93].

\section{Availability of supporting data}

The data sets supporting the results of this article are available in the TreeBase repository, ID 17805 and http:// purl.org/phylo/treebase/phylows/study/TB2:S17805 [104]. 


\section{Additional file}

Additional file 1: Accessions downloaded from GenBank. Species names and accession numbers of Artemisia and Tanacetum ITS1 + ITS2 and $\operatorname{trnH}$-psbA sequences.

\section{Abbreviations}

1Cx: Monoploid Genome Size; 2C: Holoploid Genome Size; CMA: Chromomycin $\mathrm{A}_{3}$; FISH: Fluorescent in situ Hybridisation; NOR: Nucleolar Organizer Region; PGLS: Phylogenetic Generalised Least Squares; rDNA: Ribosomal DNA (or ribosomal RNA genes); rRNA: Ribosomal RNA; TKL: Total Karyotype Length.

\section{Competing interests}

The authors declare that they have no competing interests.

\section{Authors' contributions}

$\mathrm{NO}$ and AS collected the plant materials. NO, AS, JV and SG designed the research study. NO, SG and JV performed the research experiments and TG the phylogenetic analyses. SG performed the statistical analyses and ancestral state reconstruction and drafted the manuscript. All authors made contributions to the final manuscript and read and approved its final version.

\section{Acknowledgments}

This work was supported by the Dirección General de Investigación Científica y Técnica, Government of Spain (CGL2010-22234-C02-01 and 02/BOS and CGL2013-49097-C2-2-P) and the Generalitat de Catalunya, Government of Catalonia ("Ajuts a grups de recerca consolidats", 2009SGR0439 and 2014SGR514). SG benefitted from a Juan de la Cierva postdoctoral contract from the Ministry of Economy and Competitiveness, Government of Spain NO benefitted from a fellowship from the Science, Research and Technology Ministry of Iran. Aleš Kovařik is acknowledged for supplying the rDNA probes and Spencer C. Brown for supplying internal standards for flow cytometry. We thank the technical staff of the Medicinal Plants and Drugs Research Institute, Shahid Beheshti University, who helped us with fieldwork. Ricard Alvarez, Jaume Comas, Chari González and Sonia Ruiz are acknowledged for their assistance in flow cytometric analyses. We acknowledge support of the publication fee by the CSIC Open Access Publication Support Initiative through the Unit of Information Resources for Research (URICI).

\section{Author details}

${ }^{1}$ Department of Biology, Faculty of Basic Science, Malayer University, Malayer, Iran. 'Laboratori de Botànica - Unitat associada CSIC, Facultat de Farmàcia, Universitat de Barcelona, Avinguda Joan XXIII s/n, 08028 Barcelona, Catalonia, Spain. ${ }^{3}$ Institut Botànic de Barcelona (IBB-CSIC-ICUB), Passeig del Migdia $\mathrm{s} / \mathrm{n}$, Parc de Montjuïc, 08038 Barcelona, Catalonia, Spain. ${ }^{4}$ Department of Biology, Medicinal Plants and Drugs Research Institute, Shahid Beheshti University, Evin 1983963113Tehran, Iran.

Received: 17 April 2015 Accepted: 26 June 2015

Published online: 08 July 2015

\section{References}

1. Oberprieler C, Himmelreich S, Vogt R. A new subtribal classification of the tribe Anthemideae (Compositae). Willdenowia - Ann Bot Gard Bot Museum Berlin-Dahlem. 2007:37:89-114.

2. Oberprieler $C$, Himmelreich S, Källersjö M, Vallès J, Watson L, Vogt R. Tribe Anthemideae Cass. In: Funk V, Stuessy T, Bayer R, editors. Systematics, Evolution and Biogeography of the Compositae. Washington: IAPT; 2009. p. 631-66.

3. Sonboli A, Stroka K, Kazempour Osaloo S, Oberprieler C. Molecular phylogeny and taxonomy of Tanacetum L. (Compositae, Anthemideae) inferred from nrDNA ITS and cpDNA trnH-psbA sequence variation. Plant Syst Evol. 2011;298:431-44.

4. Smith RM, Burford MD. Supercritical fluid extraction and gas chromatographic determination of the sesquiterpene lactone parthenolide in the medicinal herb feverfew (Tanacetum parthenium). J Chromatogr A 1992:627:255-61.

5. Awang DVC. Prescribing therapeutic feverfew (Tanacetum parthenium (L.) Schultz Bip., syn. Chrysanthemum parthenium (L.) Bernh.). Integr Med. 1998;1:11-3.
6. Salamci E, Kordali S, Kotan R, Cakir A, Kaya Y. Chemical compositions, antimicrobial and herbicidal effects of essential oils isolated from Turkish Tanacetum aucheranum and Tanacetum chiliophyllum var. chiliophyllum. Biochem Syst Ecol. 2007;35:569-81.

7. Bagci E, Kursat M, Kocak A, Gur S. Composition and antimicrobial activity of the essential oils of Tanacetum balsamita L. subsp. balsamita and $T$ chiliophyllum (Fisch. et Mey.) Schultz Bip. var. chiliophyllum (Asteraceae) from Turkey. J Essent Oil Bear Plants. 2008;11:476-84.

8. Yousefzadi M, Ebrahimi SN, Sonboli A, Miraghasi F, Ghiasi S, Arman M, et al. Cytotoxicity, antimicrobial activity and composition of essential oil from Tanacetum balsamita L. subsp. balsamita. Nat Prod Commun. 2009;4:119-22.

9. Esmaeili MA, Sonboli A, Ayyari Noushabadi M. Antioxidant and protective properties of six Tanacetum species against hydrogen peroxide-induced oxidative stress in K562 cell line: A comparative study. Food Chem. 2010;121:148-55

10. Karaca M, Özbek H, Akkan HA, Tütüncü M, Özgökce F, Him A, et al. Antiinflammatory activities of diethyl-ether extracts of Helichrysum plicatum DC. and Tanacetum balsamita L. in rats. Asian J Anim Vet Adv. 2009;4:320-5.

11. Vallès J, Garnatje T, Garcia S, Sanz M, Korobkov AA. Chromosome numbers in the tribes Anthemideae and Inuleae (Asteraceae). Bot J Linn Soc. 2005;148:77-85.

12. Mozzafarian V. Notes on the tribe Anthemideae (Compositae), new species, new records and new combinations for Iran. Iranian J Bot. 2005;11:115-27.

13. Djavadi S. Three new records of Tanacetum for the flora of Iran. Rostaniha. 2008;9:23-32.

14. Sonboli A, Kazempour Osaloo S, Riahi H, Mozaffarian V. Tanacetum joharchil sp. nov. (Asteraceae-Anthemideae) from Iran, and its taxonomic position based on molecular data. Nord J Bot. 2010;28:74-8.

15. Sonboli A, Oberprieler C. Insights into the phylogenetic and taxonomic position of Tanacetum semenovii Herder (Compositae, Anthemideae) based on nrDNA ITS sequences data. Biochem Syst Ecol. 2012;45:166-70.

16. Kazemi M, Sonboli A. A taxonomic reassessment of the Tanacetum aureum (Asteraceae, Anthemideae) species group: insights from morphological and molecular data. Turkish J Bot. 2014;38:1259-73.

17. Kazemi M, Sonboli A, Maivan HZ, Osaloo SK, Mozaffarian V. Tanacetum tarighii (Asteraceae), a new species from Iran. Ann Bot Fenn. 2014;51:419-22.

18. Chehregani A, Hajisadeghian S. New chromosome counts in some species of Asteraceae from Iran. Nord J Bot. 2009;27:247-50.

19. Inceer H, Hayirlioglu-Ayaz S, Guler H. Karyological studies of some representatives of Tanacetum L. (Anthemideae-Asteraceae) from north-east Anatolia. Plant Syst Evol. 2012;298:827-34.

20. Olanj N, Sonboli A, Riahi H, Osaloo SK. Karyomorphological study of nine Tanacetum taxa (Asteraceae, Anthemideae) from Iran. Caryologia. 2013;66:321-32.

21. Ghasemkhani T, Ahmadi M, Atri M. Variation of chromosome numbers in 14 populations of Tanacetum parthenium and eight populations of $T$. polycephalum in Hamedan Province, Iran. Chromosom Bot. 2013;8:103-8.

22. Semple J, Watanabe K. A review of chromosome numbers in Asteraceae with hypotheses on chromosomal base number evolution. In: Funk $V$, Stuessy T, Bayer R, editors. Systematics, Evolution and Biogeography of the Compositae. Washington: IAPT; 2009. p. 61-72.

23. Chehregani A, Mehanfar N. New chromosome counts in the tribe Anthemideae (Asteraceae) from Iran. Cytologia (Tokyo). 2008;73:189-96.

24. Siljak-Yakovlev S, Pustahija F, Vicic V, Robin O. Molecular cytogenetics (FISH and fluorochrome banding): resolving species relationships and genome organization. Methods Mol Biol. 2014;1115:309-23.

25. Garcia S, Panero JL, Siroky J, Kovarik A. Repeated reunions and splits feature the highly dynamic evolution of $5 S$ and 35 S ribosomal RNA genes (rDNA) in the Asteraceae family. BMC Plant Biol. 2010;10:176.

26. Liu B, Davis TM. Conservation and loss of ribosomal RNA gene sites in diploid and polyploid Fragaria (Rosaceae). BMC Plant Biol. 2011;11:157.

27. Mahelka V, Kopecky D, Baum BR. Contrasting patterns of evolution of $45 \mathrm{~S}$ and $5 \mathrm{~S}$ rDNA families uncover new aspects in the genome constitution of the agronomically important grass Thinopyrum intermedium (Triticeae). Mol Biol Evol. 2013;30:2065-86.

28. Garcia S, Inceer H, Garnatje T, Vallès J: Genome size variation in some representatives of the genus Tripleurospermum. Biologia Plantarum. 2005, 49:381-387

29. Garnatje T, Garcia S, Vilatersana R, Vallès J. Genome size variation in the genus Carthamus (Asteraceae, Cardueae): systematic implications and additive changes during allopolyploidization. Ann Bot. 2006;97:461-7. 
30. Pellicer J, Garcia S, Canela MA, Garnatje T, Korobkov AA, Twibell JD, et al. Genome size dynamics in Artemisia L. (Asteraceae): following the track of polyploidy. Plant Biol (Stuttg). 2010;12:820-30.

31. Maghuly F, Schmoellerl B, Temsch EM, Laimer M. Genome size, karyotyping and FISH physical mapping of $45 \mathrm{~S}$ and $5 \mathrm{~S}$ genes in two cherry rootstocks: Prunus subhirtella and Prunus incisa xserrula. J Biotechnol. 2010;149:88-94.

32. Bennett M. Nuclear DNA amounts in angiosperms and their modern uses-807 new Estimates. Ann Bot. 2000;86:859-909.

33. Mortreau E, Siljak-Yakovlev S, Cerbah M, Brown SC, Bertrand H, Lambert C. Cytogenetic characterization of Hydrangea involucrata Sieb. and H. aspera D. Don complex (Hydrangeaceae): genetic, evolutional, and taxonomic implications. Tree Genet Genomes. 2009;6:137-48.

34. De Jesus ON, de OE SS, Amorim EP, Ferreira CF, de Campos JMS, Silva G de $\mathrm{G}$, et al. Genetic diversity and population structure of Musa accessions in ex situ conservation. BMC Plant Biol. 2013;13:41.

35. Abd El-Twab M, Kondo K. Physical mapping of 5 S and 45S rDNA in Chrysanthemum and related genera of the Anthemideae by FISH, and species relationships. J Genet. 2012;91:245-9.

36. Garcia S, Lim KY, Chester M, Garnatje T, Pellicer J, Vallès J, et al. Linkage of $35 \mathrm{~S}$ and $5 \mathrm{~S}$ rRNA genes in Artemisia (family Asteraceae): first evidence from angiosperms. Chromosoma. 2009;118:85-97.

37. Keskitalo M, Lindén A, Valkonen JPT. Genetic and morphological diversity of Finnish tansy (Tanacetum vulgare L., Asteraceae). Theor Appl Genet. 1998;96:1141-50

38. Siljak-Yakovlev S, Pustahija F, Šolić EM, Bogunić F, Muratović E, Bašić N, et al. Towards a genome size and chromosome number database of Balkan Flora: C-values in 343 taxa with novel values for 242. Adv Sci Lett. 2010;3:190-213.

39. Garcia S, Hidalgo O, Jakovljević I, Siljak-Yakovlev S, Vigo J, Garnatje T, et al. New data on genome size in 128 Asteraceae species and subspecies, with first assessments for 40 genera, 3 tribes and 2 subfamilies. Plant Biosyst - An Int J Deal with all Asp Plant Biol. 2013;147:1219-27.

40. Funk V, Stuessy T, Bayer R. Systematics, Evolution, and Biogeography of Compositae. Washington: IAPT; 2009.

41. Sonboli A, Kazempour Osaloo S, Vallès J, Oberprieler C. Systematic status and phylogenetic relationships of the enigmatic Tanacetum paradoxum Bornm. (Asteraceae, Anthemideae): evidences from nrDNA ITS, micromorphological, and cytological data. Plant Syst Evol. 2011;292:85-93.

42. Leitch IJ, Soltis DE, Soltis PS, Bennett MD. Evolution of DNA amounts across land plants (Embryophyta). Ann Bot. 2005;95:207-17.

43. Garcia S, Sanz M, Garnatje T, Kreitschitz A, Mcarthur ED, Vallès J: Variation of DNA amount in 47 populations of the subtribe Artemisiinae and related taxa (Asteraceae, Anthemideae): karyological, ecological, and systematic implications. Genome. 2004, 1014:1004-1014.

44. Soltis DE, Albert VA, Leebens-Mack J, Bell CD, Paterson AH, Zheng C, et al. Polyploidy and angiosperm diversification. Am J Bot. 2009;96:336-48,

45. Garcia S, Garnatje T, Pellicer J, McArthur ED, Siljak-Yakovlev S, Vallès J. Ribosomal DNA, heterochromatin, and correlation with genome size in diploid and polyploid North American endemic sagebrushes (Artemisia, Asteraceae). Genome. 2009;52:1012-24.

46. Marques I, Draper D, Riofrío L, Naranjo C. Multiple hybridization events, polyploidy and low postmating isolation entangle the evolution of neotropical species of Epidendrum (Orchidaceae). BMC Evol Biol. 2014;14:20.

47. Leitch AR, Leitch IJ. Genomic plasticity and the diversity of polyploid plants. Science. 2008:320:481-3.

48. Parisod C, Holderegger R, Brochmann C. Evolutionary consequences of autopolyploidy. New Phytol. 2010;186:5-17.

49. Parisod C, Senerchia N. Responses of transposable elements to polyploidy. In: Grandbastien MA, Casacuberta JM, editors. Plant Transposable Elements. Berlin Heidelberg: Springer; 2012. p. 147-68.

50. Tayalé A, Parisod C. Natural pathways to polyploidy in plants and consequences for genome reorganization. Cytogenet Genome Res. 2013;140:79-96.

51. Leitch IJ, Bennett MD. Genome downsizing in polyploid plants. Biol J Linn Soc. 2004:82:651-63.

52. Otto SP, Whitton J. Polyploid incidence and evolution. Annu Rev Genet. 2000;34:401-37.

53. Wolfe KH. Yesterday's polyploids and the mystery of diploidization. Nat Rev Genet. 2001;2:333-41.

54. Soltis PS, Soltis DE. Polyploidy and Genome Evolution. Berlin Heidelberg: Springer; 2012.
55. Garcia S, Canela MÁ, Garnatje T, Mcarthur ED, Pellicer J, Sanderson SC, et al. Evolutionary and ecological implications of genome size in the North American endemic sagebrushes and allies (Artemisia, Asteraceae). Biol J Linn Soc. 2008;94:631-49.

56. Leitch IJ, Hanson L, Lim KY, Kovarik A, Chase MW, Clarkson JJ, et al. The ups and downs of genome size evolution in polyploid species of Nicotiana (Solanaceae). Ann Bot. 2008;101:805-14.

57. Renny-Byfield S, Kovarík A, Chester M, Nichols RA, Macas J, Novák P, et al. Independent, rapid and targeted loss of highly repetitive DNA in natural and synthetic allopolyploids of Nicotiana tabacum. PLoS One. 2012;7:e36963.

58. Hadjikyriakou G, Hadjisterkotis E. The adventive plants of Cyprus with new records of invasive species. Z Jagdwiss. 2002;48:59-71.

59. Mito T, Uesugi T. Invasive alien species in Japan: the status quo and the new regulation for prevention of their adverse effects. Glob Environ Res. 2004:8:171-93.

60. Bennett M. DNA Amounts in two samples of angiosperm weeds. Ann Bot. 1998:82:121-34

61. Knight CA, Ackerly DD. Variation in nuclear DNA content across environmental gradients: a quantile regression analysis. Ecol Lett. 2002;5:66-76.

62. Pandit MK, White SM, Pocock MJO. The contrasting effects of genome size, chromosome number and ploidy level on plant invasiveness: a global analysis. New Phytol. 2014;203:697-703.

63. Suda J, Meyerson LA, Leitch IJ, Pyšek P. The hidden side of plant invasions: the role of genome size. New Phytol. 2015;205:994-1007.

64. Cabral JS, Felix LP, Guerra M. Heterochromatin diversity and its co-localization with 55 and 455 rDNA sites in chromosomes of four Maxillaria species (Orchidaceae). Genet Mol Biol. 2006;29:659-64.

65. Gouja, H., Garnatje, T., Hidalgo, O., Neffati, M., Raies, A., \& Garcia, S. (2014). Physical mapping of ribosomal DNA and genome size in diploid and polyploid North African Calligonum species (Polygonaceae). Plant Systematics and Evolution, 301: 1569-1579

66. Carvalho R, Soares Filho WS, Brasileiro-Vidal AC, Guerra M. The relationships among lemons, limes and citron: a chromosomal comparison. Cytogenet Genome Res. 2005;109:276-82.

67. Da Silva AEB, Marques A, dos Santos KGB, Guerra M. The evolution of CMA bands in Citrus and related genera. Chromosome Res. 2010;18:503-14.

68. Beridze T, Tsirekidze N, Roytberg M. On the tertiary structure of satellite DNA. Biochimie. 1992;74:187-94.

69. Torrell M, Cerbah M, Siljak-Yakovlev S, Vallès J. Molecular cytogenetics of the genus Artemisia (Asteraceae, Anthemideae): fluorochrome banding and fluorescence in situ hybridization. I. Subgenus Seriphidium and related taxa. Plant Syst Evol. 2003;239:141-53.

70. Garcia S, Garnatje T, Hidalgo O, McArthur ED, Siljak-Yakovlev S, Vallès J. Extensive ribosomal DNA (18S-5.8S-26S and 5S) colocalization in the North American endemic sagebrushes (subgenus Tridentatae, Artemisia, Asteraceae) revealed by FISH. Plant Syst Evol. 2007;267:79-92.

71. Garnatje T, Hidalgo O, Vitales D, Pellicer J, Vallès J, Robin O, et al. Swarm of terminal $35 \mathrm{~S}$ in Cheirolophus (Asteraceae, Centaureinae). Genome. 2012;55:529-35.

72. Abd El-Twab MH, Motohashi T, Fujise A, Tatarenko E, Kondo K, Kholboeva SA, et al. Characterization of chromosome complement in Filifolium sibiricum (L.) Kitamura by aceto-orcein, CMA, DAPI and FISH $5 S$ and 455 rDNA. Chromosome Bot. 2011;6:75-80.

73. Dydak M, Kolano B, Nowak T, Siwinska D, Maluszynska J. Cytogenetic studies of three European species of Centaurea L. (Asteraceae). Hereditas. 2009;146:152-61

74. Garnatje T, Vallès J, Vilatersana R, Garcia-Jacas N, Susanna A, Siljak-Yakovlev S. Molecular cytogenetics of Xeranthemum $\mathrm{L}$. and related genera (Asteraceae, Cardueae). Plant Biol (Stuttg). 2004;6:140-6.

75. Vanzela ALL, Ruas CF, Oliveira MF, Ruas PM. Characterization of diploid, tetraploid and hexaploid Helianthus species by chromosome banding and FISH with 45S rDNA probe. Genetica. 2002;114:105-11.

76. Zhang $\mathrm{R}$, Zhang C-T. Isochore structures in the genome of the plant Arabidopsis thaliana. J Mol Evol. 2004;59:227-38.

77. Meyers BC, Tingey SV, Morgante M. Abundance, distribution, and transcriptional activity of repetitive elements in the maize genome. Genome Res. 2001;11:1660-76.

78. Hidalgo O, Garcia-Jacas N, Garnatje T, Romashchenko K, Susanna A, Siljak-Yakovlev S. Extreme environmental conditions and phylogenetic inheritance: systematics of Myopordon and Oligochaeta (Asteraceae, Cardueae-Centaureinae). Taxon. 2008:57:769-78. 
79. Siljak-Yakovlev S, Cartier D. Heterochromatin patterns in some taxa of Crepis praemorsa complex. Caryologia. 1986;39:27-32.

80. Abd El-Twab MH, Kondo K. FISH physical mapping of 5S, $45 \mathrm{~S}$ and Arabidopsis-type telomere sequence repeats in Chrysanthemum zawadskii showing intra-chromosomal variation and complexity in nature. Chromosome Bot. 2006;1:1-5.

81. Srisuwan S, Sihachakr D, Siljak-Yakovlev S. The origin and evolution of sweet potato (Ipomoea batatas Lam.) and its wild relatives through the cytogenetic approaches. Plant Sci. 2006;171:424-33.

82. Honda Y, Abd El-Twab MH, Ogura H, Kondo K, Tanaka R, Shidahara T. Counting sat-chromosome numbers and species characterization in wild species of Chrysanthemum sensu lato by fluorescent in situ hybridization using pTa71 probe. Chromosom Sci. 1997;1:77-81.

83. Pedrosa-Harand A, de Almeida CCS, Mosiolek M, Blair MW, Schweizer D, Guerra M. Extensive ribosomal DNA amplification during Andean common bean (Phaseolus vulgaris L.) evolution. Theor Appl Genet. 2006;112:924-33.

84. Roa F, Guerra M. Distribution of $45 \mathrm{~S}$ rDNA sites in chromosomes of plants: structural and evolutionary implications. BMC Evol Biol. 2012;12:225.

85. Knight C, Clancy R, Götzenberger L: On the relationship between pollen size and genome size. J Bot 2010, 2010. http://www.hindawi.com/journals/jb/ 2010/612017/abs/.

86. Bainard JD, Husband BC, Baldwin SJ, Fazekas AJ, Gregory TR, Newmaster SG, et al. The effects of rapid desiccation on estimates of plant genome size. Chromosome Res. 2011;19:825-42.

87. Robertson A, Rich TCG, Allen AM, Houston L, Roberts C, Bridle JR, et al. Hybridization and polyploidy as drivers of continuing evolution and speciation in Sorbus. Mol Ecol. 2010;19:1675-90.

88. Kellogg EA, Camara PEAS, Rudall PJ, Ladd P, Malcomber ST, Whipple CJ, et al. Early inflorescence development in the grasses (Poaceae). Front Plant Sci. 2013;4:250.

89. Kellogg EA, Bennetzen JL. The evolution of nuclear genome structure in seed plants. Am J Bot. 2004;91:1709-25.

90. Cerbah $\mathrm{M}$, Coulaud J: rDNA organization and evolutionary relationships in the genus Hypochaeris (Asteraceae). Journal of Heredity. 1998:312-318.

91. Geber G, Schweizer D. Cytochemical heterochromatin differentiation in Sinapis alba (Cruciferae) using a simple air-drying technique for producing chromosome spreads. Plant Syst Evol. 1987;158:97-106.

92. Schweizer D. Reverse fluorescent chromosome banding with chromomycin and DAPI. Chromosoma. 1976;58:307-24.

93. Garcia S, Garnatje T, Kovařík A. Plant rDNA database: ribosomal DNA loci information goes online. Chromosoma. 2012;121:389-94.

94. Garcia S, Gálvez F, Gras A, Kovarík A, Garnatje T. Plant rDNA database: update and new features. Database (Oxford). 2014;2014:bau063.

95. Marie D, Brown SC. A cytometric exercise in plant DNA histograms, with 2C values for 70 species. Biol Cell. 1993;78:41-51.

96. Loureiro J, Rodriquez E, Dolezel J, Santos C. Comparison of four nuclear isolation buffers for plant DNA flow cytometry. Ann Bot. 2006;98:679-89.

97. Garnatje T, Canela MÁ, Garcia S, Hidalgo O, Pellicer J, Sánchez-Jiménez I, et al. GSAD: a genome size in the Asteraceae database. Cytometry A. 2011;79:401-4.

98. Garcia S, Leitch IJ, Anadon-Rosell A, Canela MÁ, Gálvez F, Garnatje T, et al. Recent updates and developments to plant genome size databases. Nucleic Acids Res. 2014:42:D1159-66.

99. Hall T. BioEdit: a user-friendly biological sequence alignment editor and analysis program for Windows 95/98/NT. Nucleic Acids Symp Ser. 1999;41:95-8.

100. Huelsenbeck J, Ronquist F, Nielsen R, Bollback J. Bayesian inference of phylogeny and its impact on evolutionary biology. Science. 2001;294:2310-4.

101. Darriba D, Taboada G, Doallo R, Posada D. jModelTest 2: more models, new heuristics and parallel computing. Nat Methods. 2012;9:772-2

102. Akaike H. A Bayesian extension of the minimum AlC procedure of autoregressive model fitting. Biometrika. 1979;66:237-42.

103. Maddison WP, Maddison DR: Mesquite: a modular system for evolutionary analysis. Version 3.02. 2015. http://mesquiteproject.org.

104. Garcia S. The striking and unexpected cytogenetic diversity of genus Tanacetum L. (Asteraceae): a cytometric and fluorescent in situ hybridisation study of Iranian taxa. TreeBase 2015.

105. Sonboli A, Olanj N, Pourmirzaei A. Biosystematics and phylogeny of Tanacetum fisherae, a new record from Iran. Rostaniha. 2011:12:165-75.

\section{Submit your next manuscript to BioMed Central and take full advantage of:}

- Convenient online submission

- Thorough peer review

- No space constraints or color figure charges

- Immediate publication on acceptance

- Inclusion in PubMed, CAS, Scopus and Google Scholar

- Research which is freely available for redistribution

Submit your manuscript at www.biomedcentral.com/submit 